\title{
PROBLEM PENGELOLAAN MADRASAH ALIYAH DAN SOLUSINYA
}

\author{
Nur Ahid"
}

\begin{abstract}
Many High Schools (Aliyah) in Indonesia arefaced with one of thefdlowing prodems low qperational expenditure, poor human resures, unsettled contrad with the teachers, small number of the teaches, andpoor farilities Thispaper tries tospeak of thepradical waystocometotems withsurhproblems Thesepradical ways-someof whicharerdated to money areinfactidkals Theseidkels in oneway or another are the foundations for the pradical problems that ar schods face By ideals we mean sum values as detemination, disaipline, andright visionfor theshod. Thepaper arguesthat monejisnd a magicstidk that maysdveall proddems. hekeyisthat all dements of shod mist usethebest they havetorealizethebest they vant to ahieve Practical prddensmay besolvedbyidkels, dosessionsand dreams In a cauntry wheremong is rare, the vision and orientation of ar education should dhange the harader of the eelurated frombing mone-criented toidealscriented
\end{abstract}

Keywords: pradical prodens, madrasah, idkals

\section{Pendahuluan}

Madrasah dari akar kata darasa (belajar) mempunyai arti tempat belajar. ${ }^{1}$ Padanan madrasah dalam bahasa Indonesia adalah sekolah, lebih dikhususkan lagi sekolah-sekolah agama Islam. ${ }^{2} \mathrm{D}$ alam Shater Engydopedia of Islam madrasah diartikan name of on institution where the Islamic saiene are sudied" ${ }^{3}$ Madrasah sebutan bagi sekolah agama Islam adalah tempat proses belajar mengajar ajaran Islam secara formal yang mempunyai kelas dan kurikulum dalam bentuk klasikal. Padanan kata madrasah dalam bahasa Indonesia adalah sekolah.

Madrasah sebagai lembaga pendidikan Islam dalam bentuk pendidikan formal sudah dikenal sejak tahun 1066/ 1067 M (459 H) di Baghdad yang didirikan oleh Niz\}a>m al-Mulk, seorang Perdana Menteri Dinasti Saljuk. ${ }^{4}$ Ia adalah salah satu di antara beberapa orang yang paling terpelajar pada zamannya, yang sangat menguasai $\mathrm{H}$ \{adi>th, dan merupakan salah seorang di antara ahli teori politik Islam terbesar, sebagaimana ditunjukkan dalam karyanya yang terkenal Siya $>\operatorname{sah} \mathrm{Na}>\mathrm{mah}^{5}$

Pendirian madrasah ini telah memperkaya khazanah lembaga pendidikan di lingkungan masyarakat Islam, karena pada masa sebelumnya masyarakat Islam hanya mengenal pendidikan tradisional di masjidmasjid dan da>r al-kutta $>$ b Madrasah-madrasah yang didirikan di seluruh kekhalifahan dibiayai secara melimpah. Ia melengkapi madrasah-madrasah tersebut dengan perpustakaan, profesor-profesor terbaik *Sekolah Tinggi Agama Islam Negeri (STAIN) Kediri, Jawa Timur

${ }^{1}$ Lihat A.W. Munawir, KamısAl-MunaunirA ArabIndonesa(Surabaya: Pustaka Progresif, 1997), 398.

${ }^{2}$ Team Penulis, Ensklqpedi Indonesia, 4 (Jakarta: Ikhtiar Baru, 1983), 207.

${ }^{3} \mathrm{HAR}$ Gibb, and Kramers JH, Shater Engdqpedia of Idam (Lieden: EJ, Brill, 1961), 300

${ }^{4}$ Mehdi Nakosteen, History of Isamic Origins of Westem Education A.D. 800-1350, with an Introdurtion to Medieal Musim Eduration, terj. Joko S Kahar dkk. (Colorado: University of Colorado Press, Boulder, 1964), 51.

${ }^{5} \mathrm{Di}$ antara para pendiri sekolah-sekolah Islam yang terkemuka, perlu juga disebutkan di sini, yakni al-Ma'mun (meninggal 833 M; $218 \mathrm{H}$ ), yang menyokong dan memberikan dana kepada pusat pendidikan Muslim terbesar di Bagdad, yakni Baitul Hikmah yang terkenal, yang juga sebagai instrument dalam penerjemahan karya-karya Yunani, Persia dan Hindu oleh para ilmuan terbesar pada masa itu. Nuruddin (meninggal 1173 M.; 569 H.), Sultan kerajaan Syria yang setelah bubarnya kerajaan Saljuk, kemudian mendirikan beberapa sekolah di D amaskus dan di seluruh kerajaannya, termasuk Mesir, Saladin (meninggal 1193 M.; 589 H.), yang memperluas sistem sekolah di Syria dan Mesir.

${ }^{6}$ A hmad Syalabi, SgarahKdardayaanIdam Terj. Muhtar Yahya (Jakarta:Jayamurni, 1970), 110 dan Philip K. Hitti, Histaryof the 
yang dapat diperoleh, dan sistem beasiswa untuk membantu semua mahasiswa.

Kajian tentang munculnya madrasah di dunia Islam, banyak ahli sejarah berbeda pendapat. Syalabi menyatakan bahwa madrasah yang mula-mula muncul di dunia Islam adalah madrasah Niz $\}$ amiyah yang didirikan oleh Niz am al-Mulk, perdana menteri Dinasti Saljuk, pada tahun 1066-7 M. Pendapat seperti ini juga dikemukakan oleh Philip K. Hitti. ${ }^{6}$ Sedangkan Athiah al-Abrasyi, mengutip dari alMaqrizi, mengemukakan bahwa Madrasah al-Baihaqiyah adalah madrasah yang pertama didirikan pada akhir abad ke-4 H (abad ke-11 M). ${ }^{7}$ Hampir serupa dengan Athiyah, Richard W. Bulliet berpendapat bahwa dua abad sebelum Madrasah Niz\}amiyah muncul, di Nisapur sudah berdiri madrasah, yaitu Miyan Dahiyah. ${ }^{8}$

Madrasah sebagai lembaga pendidikan Islam di Indonesia telah muncul dan berkembang seiring dengan masuk dan berkembangnya Islam di Indonesia. Madrasah tersebut telah mengalami perkembangan jenjang dan jenisnya seirama dengan perkembangan bangsa Indonesia, semenjak kesultanan, masa penjajahan dan masa kemerdekaan. Perkembangan tersebut telah mengubah pendidikan dari bentuk pengajian di rumah-rumah, terus ke mushalla, masjid dan ke bangunan sekolah seperti bentuk madrasah yang kita kenal saat ini. ${ }^{9}$

Salah satu cita-cita umat Islam Indonesia yang sering dikumandangkan para pemimpin umat menjelang kemerdekaan ataupun setelah kemerdekaan adalah adanya lembaga pendidikan yang mampu menyiapkan calon ulama yang cendekia dan cendekia yang ulama. D engan istilah lain, menyiapkan anak didik yang dapat memadukan iptek dan imtaq. Inilah harapan utama masyarakat pada madrasah. ${ }^{10}$

Harapan tersebut sulit diwujudkan setelah adanya SK B 3 Menteri tahun 1975 yang berimplikasi pada beban kurikulum 70 \% umum 30 \% agama. A palagi setelah UU Sisdiknas No. 2 tahun 1989 yang menyamakan kurikulum sekolah dengan madrasah, yang membedakan hanya jumlah pelajaran ciri khas (agama). Melalui SKB ini memang status madrasah disamakan dengan sekolah berikut jenjangnya: MI sejajar dengan SD, MTs sejajar dengan SMP, dan MA sejajar dengan SMA. D engan SKB ini pula alumni MA dapat melanjutkan ke Universitas umum, dan alumni SMA dapat melanjutkan studi ke IAIN. Karena madrasah diakui sejajar dengan sekolah umum, komposisi kurikulum madrasah harus sama dengan sekolah umum. Efek penyamaan kurikulum ini adalah bertambahnya beban yang harus dipikul madrasah. Di satu pihak, ia harus memperbaiki mutu pendidikan umumnya setaraf dengan standar yang berlaku di sekolah. Di lain pihak, bagaimanapun juga madrasah, sebagai lembaga pendidikan Islam, harus menjaga agar mutu pendidikan agamanya tetap baik. Namun, dengan

Arab(London: MacMillan Press Ltd., 1974), 410.

${ }^{7}$ A thiyah al-A brasyi, Dasar-dasarPdkdk PendidikanIsam terj. Bustami A. Gani dan Djohar Basri L.I.S (Jakarta: Bulan Bintang, 1993), 79.

${ }^{8}$ Richard W. Bullier, The Patriaanof Nisaphur: a StudyinMedieal IdamicSocial Histary(Harvard University Press, 1972), 48.

${ }^{9}$ Husni Rahim, "Anatomi Madrasah di Indonesia," dalam Edukasi: Jurnal Penelitian Pen-didikan Agama dan Keagamaan, Volume 2, Nomor 2, A pril-Juni 2004, 23.

${ }^{10}$ Harapan ini, kini mendapat peluang yang sangat besar, lebih-lebih dengan telah diundangkannya Undang-undan Sistem Pendidikan Nasional Nomor 2 Tahun 1989, berikut Peraturan Pemerintah dan perundangan lainnya yang mengakui madrasah sebagai sekolah umum yang berciri khas Islami. Kurikulum madrasah adalah sama persis dengan kurikulum sekolah umum, plus ciri khas keislamannya. D engan kata lain, madrasah mempersiapkan anak didiknya mampu dalam sains dan teknologi, tetapi tetap dengan identitas keislaman. Mmadrasah sebagai sekolah umum yang berciri khas Islam yang mampu memadukan kekuatan iptek dan imtaq.

${ }^{11}$ Maksum, Madrasah; Sjarah danPekenbancannya (Jakarta: Logos Wacana Ilmu, 1999), 51-112.

${ }^{12}$ Husni Rahim, "Anatomi Madrasah di Indonesia", dalam Edukasi: Jurnal Penelitian Pendidikan Agama dan keagamaan, 
penguasaan ilmu-ilmu agama hanya 30 \% termasuk bahasa A rab, kiranya sulit bagi lulusan MA mampu menguasai ilmu agama ketika masuk ke IAIN, apalagi menjadi calon-calon ulama.

D engan beban $70 \%$ umum dan $30 \%$ agama, untuk mewujudakan calon-calon ulama dan kelangkaan ulama akan terjadi di masa yang akan datang, maka perlu adanya rekonstruksi MA di Indonesia. O leh karenaitu, maka penelitian ini adalah mencari penyebab masalah atau mengurai problem lalu merekonstruksi dengan mencari solusi, kemudian hasilnya bisa menjadi konstribusi untuk semua pihak, baik oleh pemerintah di dalam mengambil kebijakan dan keputusan, pengelola dan pelaksana pendidikan, masyarakat maupun pengguna lulusan. D ari latar belakang di atas, dirumuskan fokus penelitian ini adalah: (1) Problem apa saja yang terjadi pada Madrasah Aliyah di Indonesia, (2) Apa akibat problem tersebut? lalu (3) Bagaimana merekonstruksi-solusinya?

\section{Kajian Terdahulu dan Perspektif Teori.}

Karel A. Steenbrink melakukan penelitian tentang Pesantren, Madrasah dan Skkdah: Pendidkan IdamdalamKunun Modam Penelitian tersebut lebih menekankan pada pesantren, sedangkan madrasah dan sekolah sifatnya hanya sepintas kilas, itupun tidak mengungkapkan problem, apalagi mencari solusi.

Sedang Maksum, ${ }^{11}$ mengkaji tentang Madrasahr SejarahdanPekkenbangamya Titik tekan penelitian ini pada perkembangan institusi madrasahnya, yaitu membicarakan tentang madrasah di zaman Islam klasik dan sejarah pertumbuhan madrasah di Indonesia secara umum.

Sama halnya Husni Rahim tentang “A natomi Madrasah” dalam Jurnal PenditianPendidkanAggma dan keagaman, ia juga memokuskan penjelasannya pada perkembangan institusi madrasah di Indonesia, seperti Madrasah Aliyah Negeri, Swasta, Ketrampilan dan lain sebaginya. ${ }^{12}$

Dari hasil penelitian yang ada, pada umumnya lebih memokuskan pada perkembangan institusi sekolah atau madrasah secara garis besar dan sifatnya umum, belum spesifik, maka di sini peneliti lebih mengarah pada Rekonstnkisi Madrasah Aliyah d Indonesia: Mengurai Proddemdan Mencan Sdusi.

Persoalan-persoalam atau problem pendidikan di Indonesia adalah: 1) sistem pendidikan yang masih bermasalah, 2) kurangnya pengakuan terhadap mutu lulusan, 3) kualitas guru masih rendah dan salah pegang materi pelajaran, 4) imputnya rendah, 5) sarana dan prasarana kurang memadai, 6) kurangnya tanggung jawab oleh semua pihak (pemerintah, orang tua dan masyarakat), 7) kurangnya dana yang memadai dan atau memadai tetapi tidak lancar, 8) kurikulum yang digunakan tidak relevan dengan kebutuhan dan bebannya terlalu berat, 9) orientasi kurikulum tidak jelas, 10) dalam proses belajarmengajar, siswa untuk kurikulum, bukan kurikulum untuk siswa, sehingga yang terjadi adalah bebannya terlalu berat, pencapaian target dan pemaksaan, 11) lemahnya managemen pendidikan, 13) keberhasilan pendidikan hanya diukur ranah kognitif saja, sedangkan ranah afektif dan psikomotorik kurang mendapat perhatian, 14) gelar menjadi suatu tuntutan aturan, sedangkan kualitas kurang mendapat perhatian. ${ }^{13}$

Handayani mengatakan bahwa persoalan pendidikan di Indonesia antara lain adalah: 1) kurangnya tenaga guru yang profesional, 2) kinerja dan kesejahteraan guru yang belum optimal, 3) proses pembelajaran yang konvensional, 4) keterbatasan anggaran pendidikan, 5) rendahnya mutu SD M pengelola pendidikan, 6) mutu lulusan dan life skill yang dihasilkan tidak sesuai kebutuhan, dan 7)

Volume 2, Nomor 2, April-Juni 2004, 24.

${ }^{13}$ H.A.R. Tilar, BdbeapaAgendaReformas PendidikanNasional dalamPespektif Abad21, (Magelang: Indonesia Tera, 1999), 30 51, lihat Sudarwan D anim, Agenda Penbahanuan SistemPendidikan(Yogyakarta: Pustaka Pelajar, 2003), 6-8, lihat Sutjipto, 
pendidikan yang belum berbasis masyarakat dan lingkungan. ${ }^{14}$

Penelitian ini menggunakan pendekatan kualitatif, yaitu penelitian yang bertujuan mendeskripsikan keutuhan suatu masalah atau problem yang ada di Madrasah Aliyah. Dengan kata lain, pendekatan kualitatif ini memusatkan perhatian pada problem-problem yang ada. ${ }^{15}$ Problem yang dimaksud adalah masalah-masalah yang terjadi di Madrasah Aliyah.

Pendekatan kualitatif ini dapat dipandang sebagai prosedur penelitian yang menghasilkan data deskriptif berupa kata-kata tertulis atau lisan dari orang-orang yang terlibat dalam pendidikan yang dapat ditemui, diamati, atau diminta informasi, bahwa problem tersebut sebagai satu kesatuan yang masing-masing berdiri sendiri tetapi satu sama lain saling berkaitan dan merupakan satu kesatuan yang bulat dan menyeluruh. D alam hal ini teori dasar yang dipakai adalah pendekatan fenomenologis yang berupaya memahami persoalan yang ada, baik dari pelaku maupun lembaga yang menimbulkan problem. ${ }^{16}$

Penelitian kualitatif lebih bersifat natural, deskriptif, induktif dan menemukan makna dari suatu problem. Naturalistik, berarti konteks kebulatan yang menyeluruh yang tidak akan difahami dengan membuat isolasi atau eliminasi sehingga terlepas dari konteksnya. D eskriptif, tujuan utamanya adalah menerangkan apa adanya atau apa yang sekarang ada. Induktif berarti dari problem satu tempat dan tempat yang lain lalu digeneralisakikan menjadi problem umum. D engan sifat ini berarti bahwa gambarangambaran yang berkembang di Madrasah Aliyah didasarkan atas kenyataan-kenyataan empiris sebagaimana dapat difahami dari permasalahan yang telah dirumuskan. ${ }^{17}$

Penentuan informan dalam penelitian ini didasarkan pada kriteria yang disarankan oleh D eddy Mulyana, ${ }^{18}$ Guba dan Lincoln, ${ }^{19}$ William J. Fieldstead: ${ }^{20}$ a) enkulturasi penuh, artinya subyek cukup lama atau paling tidak lebih tahu, sehingga memiliki pengetahuan khusus atau informasi atau dekat dengan situasi yang menjadi fokus penelitian, b) keterlibatan langsung, subyek yang masih aktif di lingkungan aktifitas yang menjadi sasaran penelitian, c) subyek yang masih mempunyai waktu untuk dimintai informasi oleh peneliti, d) subyek memiliki otoritas dan kapasitas memberikan informasi, e) subyek yang tidak mengemas informasi, tetapi memberikan informasi yang sebenarnya.

Adapun metode pengumpulan data yang digunakan dalam penelitian adalah wawancara, ${ }^{21}$ observasi $^{22}$ dan dokumentasi. ${ }^{23}$

\section{Temuan Data}

a. Aspek Institusi

PendidikanGunu: Masalahdan Strateej Pemeahannya, (Yogyakarta: Pustaka Pelajar, 2003), 92-113, lihat Abdul Munir Mulkhan, Dilema Madrasah d Antara Dua Dunia, Kompas, Sabtu, 22 September 2001 lihat Syamsul Arif Rakhmadani, Problematika Pendidikandi Indonesia, http://bz.blogfam.com/bzaktual/ menyoal problematika -pendidika/dan 10,5

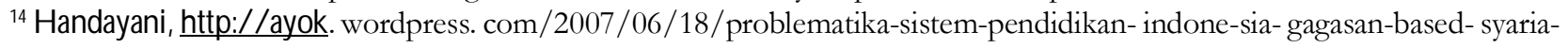
education/ Ahad, 6Januari 2007

${ }^{15}$ Parsudi Suparlan, PengantarMkoddog PenditianKualitatif(Semarang: Fakultas Tarbiyah, Majalah Media edisi 14 tahun 1993), 19.

${ }^{16}$ Lexy J Moleong, Međodog் PenditianKualitatif(Bandung: Remaja Rosda Karya, 1991), 3.

${ }^{17}$ Noeng Muhadjir, MehodePenditian Kuantitatif(Y ogyakarta: Rake Sarasin, 2002), 148.

${ }^{18}$ D eddy Mulyana, Meoddog Penditian Kualitatif, Paradigma Banu Ilmu Kommikas dan Ilmu Sosial lainnya, (Bandung: Remaja Posdakarya, 2001), 182.

${ }^{19}$ E.G. G uba dan Lincoln, Y, EffetiveEvaluation, ImproingtheUscfulness of EvaluationResults through Responsiveand Naturalistic 
Jumlah madrasah A liyah sebagaian besar berstatus swasta yang kebanyakan mengandalkan sumber pembiayaan pendidikan dari masyarakat. D ari segi substansi, mayoritas Madrasah Aliyah telah otonom dan bahkan terkesan sebagai institusi yang dibiarkan hidup dengan sendirinya. Problem yang sangat krusial adalah performan mutu pengetahuan umum di Madrasah Aliyah masih tertinggal dari Sekolah Menengah Umum. Kasus-kasus profesionalitas guru seperti kasus mismatch(salah kamar) dan under-qualified (tidak layak) masih sering kita jumpai.

D ampak positif reformasi total, adalah terjadinya pergeseran paradigma dari sistem pemerintahan yang bercorak sentralistik mengarah kepada sistem pemerintahan yang desentralistik. Dampak inilah yang melahirkan UU No. 22 Tahun 1999 tentang Pemerintah Daerah, dan UU No. 25 Tahun 1999 tentang Perimbangan Keuangan antara Pemerintah Pusat dan Daerah.

Madrasah Aliyah sebagai lembaga pendidikan yang dikelola D epartemen Agama setelah disahkannya UU No. 22 Tahun 1999 tentang Pemerintah Daerah dan UU No. 25 Tahun 1999 tentang Perimbangan Keuangan antara Pemerintah Pusat dan Daerah, muncul problem menganai status madrasah. Ketentuan UU No. 22 tahun 1999 pasal 7 ayat (1) menyatakan bahwa kewenangan daerah mencakup kewenangan dalam bidang seluruh bidang pemerintahan, kecuali kewenangan dalam bidang politik luar negeri, pertahanan keamanan, peradilan, moneter dan fiskal, agama serta kewenangan bidang lain.

Di lain pihak pasal 11 ayat (2) menyatakan bahwa pendidikan dan kebudayaan adalah salah satu dari 11 (sebelas) bidang yang wajib dilaksanakan daerah kabupaten dan daerah kota. ${ }^{24}$ Pertanyaan lanjutan yang muncul dari penafsiran terhadap dua pasal di atas adalah apakah madrasah termasuk dalam bidang pendidikan ataukah bidang agama? D ari sini muncul multi tafsir, di antaranya:

Petama, mengatakan bahwa pendidikan agama dan pendidikan lain yang diasuh D epartemen Agama tidak diotonomikan. Ini berarti pendidikan di D epartemen Agama dikatagorikan sebagai bagian dari sistem agama, bukan bagian dari sistem pendidikan nasional. Kedua, mengatakan bahwa pendidikan agama dan pendidikan yang dikelola D epartemen Agama adalah bagian dari sistem pendidikan nasional. Karena pendidikan diotonomikan, maka pendidikan di lingkungan D epartemen Agama semestinya juga harus diotonomikan. Hal ini sejalan dan dimungkinkan oleh penjelasan dari pasal 7 ayat 1 yaitu; "khusus di bidang keagamaan sebagian kegiatannya dapat ditugaskan oleh Pemerintah Pusat kepada D aerah sebagai upaya meningkatkan keikutsertaan daerah dalam menumbuh kembangkan kehidupan beragama". Ini bermakna tidak diotonomikan agama, tetapi masih memberi peluang penugasan bidang-bidang tertentu (pendidikan agama) kepada Daerah.

\footnotetext{
Approades(San Fransisco:Jossey-Bass, Inc, 1981), 78

${ }^{20}$ William J. Fieldstead, ed. QualitativeMethoddogy: Firsthand Invdvement with theSocial Wodd Chicago: Markham, 1970), 217 231.

${ }^{21}$ Kaelan, MetodePenditianKualitatif BidangFilsafat(Yogyakarta: Paradigma, 2005), 202 dan lihat Suharmisi Arikunto, Prosedur Penditian(Jakarta: Rineka Cipta, 1993), 196.

${ }^{22}$ Ibid D eddy Mulyana, Metoddog PenditianKualitatif, 182 Suharmisi Arikunto, ProsedurPenditian(Jakarta: Rineka Cipta, 1993), 1.

${ }^{23}$ Moh. Nazir, MetodePenditian (Jakarta: G halia Indonesia, 1999), 56 dan lihat Suharmisi Arikunto, Prosedur Penditian Suatu PendkkatanPrakttk (Jakarta: Rineke Cipta, 2002), 206 Abdullah Khozin Afandi dkk., BukuPenunjangBefikir TernitisMaranrang Proposal (Surabaya: Pascasarjana IAIN Sunan Ampel, 2006), 154.

${ }^{24}$ Adalah 1) Pelayanan Umum; 2) Pertahanan; 3) Ketertiban dan Kea-manan; 4) Ekonomi; 5) Ling-kungan Hidup; 6) Perumahan dan Fasilitas Umum; 7) Kesehatan; 8) Pariwisata dan Budaya; 9) Agama; 10) Pendidikan; 11) Perlindungan Sosial.

${ }^{25}$ http://www.kompas.co.id/ kompas-cetak/ 0406/28/ humaniora/ 1112151. htm, 26 Nopem-ber 2007
} 
Di sisi lain melalui UU No. 25 Tahun 1999 tentang Perimbangan Keuangan antara Pemerintah Pusat dan D aerah ditentukan bahwa fokus pelaksanaan otonomi daerah adalah di D aerah Kabupaten dan D aerah Kota. Untuk itu, sebagian besar sumber pembiayaan nasional akan dilimpahkan lebih banyak ke daerah sesuai dengan potensi dan kemampuan perekonomian daerah yang berbeda-beda. Kewenangan pemerintah terbatas dengan dukungan sumber pembiayaan yang terbatas pula. Sementara itu peranan daerah propinsi sebagai daerah otonom maupun sebagai wilayah administrasi lebih terbatas dengan perimbangan sumber keuangan yang lebih sedikit.

Abdul Azis ${ }^{25}$ mengatakan: $\mathrm{G}$ una memperkecil kesenjangan mutu antara madrasah dan sekolah umum, pemerintah perlu melakukan pembinaan lintas sektoral dengan melibatkan departemen atau instansi terkait. Faktor yang menghambat perkembangan madrasah selama ini tidak hanya soal minimnya dana opersional, tetapi juga keterbatasan tenaga guru, ketidak jelasan status guru, ketidak layakan kualifikasi guru, ketidak layakan ruang kelas, dan tidak proporsionalnya pembiayaan siswa.

D ata 90.441 guru MA, dari 65.073 atau 72,0 persen di antaranya sudah memiliki kualifikasi pendidikan S1 atau lebih, sedangkan 25.368 atau 28,0 persen guru lainnya berpendidikan kurang dari $\mathrm{S} 1{ }^{26}$

Problem berikutnya adalah ketersediaan jumlah guru. Pada tahun ajaran 2004/ 2005, kebutuhan guru MA berjumlah sebanyak 114.866 guru, sedang guru yang tersedia hanya 90.411, maka terjadi kekurangan guru sebanyak 24.425 guru. ${ }^{27}$

Problem berikutnya adalah ruang belajar, dari jumlah ruang belajar MA adalah 26.078 dan hanya 19.455 atau 74,6 \% yang baik. Sedangkan sisanya rusak ringan dan rusak berat. Hingga pada tahun pelajaran 2004/ 2005 terdapat kekurangan ruang belajar sebanyak 6.248, yang terdiri dari 2.931 ruang belajar baru dan 3.317 ruang belajar yang harus diperbaiki. ${ }^{28}$

Kalau kita mau jujur bahwa keberadaan Madrasah Aliyah di seluruh Tanah Air saat ini sangat memprihatinkan. Itu antara lain terlihat dari sisi ketersediaan guru, status guru, kondisi ruang belajar, tingkat pembiayaan (unit cost) siswa, hingga tidak adanya standarisasi mutu madrasah. D ibandingkan dengan sekolah-sekolah umum, keberpihakan negara terhadap madrasah selama ini sangat senjang. Sudah saatnya dilakukan penanganan secara terpadu.

Secara keseluruhan, jumlah guru yang mengajar MA adalah 90.441 guru, terdiri dari 14.778 atau 16,3 persen guru PNS, dan 75.663 atau 83,7 guru non-PNS. Jumlah guru PNS pada Madrasah Aliyah swasta (adalah 2.592 atau 3,7 persen dari 69.438 guru yang mengajar pada madrasah swasta. ${ }^{29}$

Madrasah ini sendiri secara institusi telah diakui oleh UUSPN No. 2 Tahun 1989 sebagai bagian dari sistem pendidikan nasional, bahkan di UUSPN No. 20 Tahun 2003 pasal 18, ayat 2 dan 3 , secara institusi sama dengan sekolah umum, sehingga kedudukan, hak dan eksistensi madrasah dengan sekolah umum sama, namun di dalam realisasi undang-undang tersebut memunculkan berbagai penafsiran sebagaimana di atas, dan memunculkan berbagai problem. Problemnya adalah:

\footnotetext{
${ }^{26}$ D epag RI, DaraSatatistik DirkttaratJendral KdenbagaanAgamaIsam(Jakarta: Sekretariat Bagian D ata dan Informasi Pendidikan, Dirjen Bagais, 2005), 25-26

${ }^{27}$ Ibid., 23.

${ }^{28}$ Ibid., 25.

${ }^{29}$ Ibid., 21.

${ }^{30}$ Yahya Umar, Konsultasi dan Rapat Kerja dengan Pimpinan PTAIS se Kopertais Wilayah IV Surabaya, 2006
} 
1) Lempar tanggung jawab

Siapa yang bertanggung jawab penanganan pembinaan mutu dan kualitas para guru bidang MAFIKIBB (Matematika, Kimia, Biologi dan Bahasa Inggris) yang ada di Madrasah Aliyah. Departemen Agama atau Departemen Pendidikan Nasional. Sekalipun mereka lulusan dari Universitas Umum sesuai dengan jurusan yang mereka ajar, tetapi lalu siapa yang membina rumpun ilmu atau mata pelajaran tersebut ketika menjadi guru, sudah beberapa tahun, sebab ilmu itu selalu terus berkembang, sedangkan yang ahli dalam bidang tersebut adalah orang D iknas. Akibatnya, kurang adanya pembinaan terhadap para guru bidang MAFIKIBB. Bisa saja D epag akan mengatakan itu bukan wilayah ilmu saya, sedangkan D iknas mengatakan itu bukan pegawai saya. A kibatnya guru-guru bidang MAFIKIBB yang mengajar di Madrasah Aliyah secara umum kualitasnya masih di bawah SMA. Solusinya: 1) Memberikan subsidi untuk belajar yang sejalur ke jenjang yang lebih tinggi, 2) Mengadakan pembinaan gabungan yang terpadu (guru umum yang ada di madrasah dibina oleh Diknas, sedang guru agama, baik yang ada di madrasah maupun di sekolah umum dibina oleh Depag), bisa melalui pelatihan dan sebagainya.

2) Diskriminasi anggaran pendidikan

Pada saat penelitian ini dilakukan orang ramai memperbincangkan tentang alokasi anggaran pendidikan yang minim, di dalamnya terselip persoalan besar yang hingga saat ini belum terselesaikan juga, yaitu soal perimbangan keuangan pendidikan agama dan umum. Mengapa perimbangan keuangan pendidikan agama dan umum ini menjadi penting, mengingat sudah sangat lama pendidikan agama diperlakukan sebagai lembaga kelas dua dari pendidikan umum. Alokasi anggarannya pun disebut-sebut hanya atas belas kasihan pendidikan umum yang ditahbiskan oleh negara sebagai lembaga kelas satu dengan berbagai keistemewaan menyertainya. ${ }^{30}$

Harus diakui bahwa sejak masing-masing wilayah pendidikan dikelola berbagai departemen yang berbeda, satu di bawah koordinasi D epartemen Agama, lainnya di bawah koordinasi D epartemen Pendidikan Nasional, lainnya di bawah D epartemen Pertahanan (AKABRI), lainnya di bawah Kepolisian Republik Indonesia (AK PO L), lainnya di bawah D epartemen D alam Negeri (STPD N) dan seterusnya, telah muncul dilema-dilema, terutama dilema anggaran dan koordinasi kebijakan yang sering terjadi duplikasi dan tumpang tindih, malah kalau bukan benturan kepentingan, sehingga tatkala isu ini mencuat dan menguat di parlemen dan elemen-elemen strategis masyarakat, banyak orang berharap agar persoalan yang urgen dan begitu vital ini, supaya betul-betul diperhatikan secara serius dan ditindak lanjuti secara konkrit bagi siapa saja yang memiliki committed dan concem terhadap gagasan perimbangan keuangan bagi penyelenggaraan pendidikan tersebut.

Problem yang sangat vital adalah apakah perimbangan keuangan (anggaran) antara pendidikan D epag dan Diknas ini dapat digarap dengan sungguh-sungguh sampai menuai kenyataan, sebab elemen pendidikan agama (D epag) yang ada selama ini sudah terlampau lama mengalami proses ketidak-adilan dalam pengalokasian anggaran pendidikan. Akibatnya, seluruh infra stuktur dan supra struktur pendidikan agama (D epag), dalam hal ini tampak jelas pada

\footnotetext{
${ }^{31} \mathrm{http}: / /$ www.sinarharapan.co.id/ berita/ 0707/ 28/ opi01.html A had, 6 Januari 2007

${ }^{32}$ Berdasarkan "kesepakatan 4 Juli 2005" antara D PR dan Pemerintah diperolehlah skenario progresif pemenuhan anggaran pendidikan dengan menetapkan kenaikan bertahap 2,7\% pertahun hingga 2009 dengan rincian kenaikan 9,29\% (2005), 12,01\%
} 
madrasah-madrasah kondisinya begitu memprihatinkan dibandingkan saudara kembarnya pendidikan umum. Pemerintah di dalam memberikan anggaran terhadap pendidikan agama (D epag) jauh lebih kecil dibanding dengan pendidikan umum (Diknas), padahal dana D epartemen Agama yang kecil itu tidak hanya untuk pendidikan saja, tetapi dibagi-bagi untuk kebutuhan selain pendidikan.

Alokasi anggaran untuk pembinaan dan pengem-bangan sarana madrasah belum seimbang dibanding dengan anggaran yang diberikan kepada sekolah-sekolah yang sekarang berada dalam naungan D epdiknas. Akibatnya, fasilitas dan sarana pendidkan di madrasah secara umum tidak sebagus yang dimiliki di sekolah umum. Tetapi, memang harus kita akui bahwa anggaran pendidikan di Indonesia masih rendah sekali. Pemerintah sepertinya belum memiliki pditical will untuk memperbesar anggaran pendidikan tersebut.

Lemahnya pditical will (kemauan politik) pemerintah terhadap pendidikan sesungguhnya sangat menentukan kemajuan pendidikan suatu bangsa. Seperti yang dinyatakan Anita Lie dalam artikelnya yang berjudul "Pendidikan dalam D inamika G lobalisasi" mengemukakan bahwa untuk memajukan dunia pendidikan dibutuhkan suatu komitmen dan kemauan yang kuat dari tampuk kepemimpinan nasional. ${ }^{31}$

Sesuai Pasal 31 Ayat (4) UUD 1945 pemerintah memiliki kewajiban konstitusi (constitutional ddication) untuk memprioritaskan anggaran pendidikan sekurang-kurangnya 20\% dari APBN dan APBD guna memenuhi kebutuhan penyelengaraan pendidikan nasional. Juga ditegaskan dalam UU organiknya, yaitu UU No. 20 tahun 2003 tentang Sisdiknas bahwa dana pendidikan selain gaji pendidik dan biaya pendidikan kedinasan harus dialokasikan minimal 20\% dari APBN pada sektor pendidikan dan minimal 20\% dari APBD. ${ }^{32}$

\section{b. Aspek Kurikulum}

Kurikulum Madrasah Aliyah di Indonesia ini selalu berubah-ubah, bahkan belum jelas hasilnya, sudah dirubah lagi, belum bisa dipahami oleh kebanyakan para guru, sudah berubah lagi, baru dilaksanakan belum sepenuhnya sudah ganti lagi, inilah yang menjadikan problem. Hal ini disampaikan oleh Moh. Harisuddin ${ }^{33}$ bahwa sistem aturannya selalu berubah, contoh: menggunakan kolom 7, kolom 8, penilaian kognitif, afektif, psikomotirik, penilaian sebagian atau semuanya, akibatnya membingungkan para guru.

Sekalipun buku pedoman kurikulum sudah diserahkan oleh D epartemen Agama Pusat kepada masing-masing satuan pendidikan di daerah, tetapi kenyataannya dalam hal ini madrasah belum berani mengganti, apalagi mengurangi jumlah bidang studi yang sudah tertulis dalam buku pedoman Model Kurikulum Tingkat Satuan Pendidikan (KTSP) Madrasah Aliyah yang di Edarkan oleh Direktorat Pendidikan Madrasah, karena berkaitan dengan Ujian Nasional, kalau mau jujur ternyata jumlah bidang studi itu jumlahnya terlalu banyak, sehingga kurikurum tersebut menimbulkan problem, sebagaimana Basuki Rahmat Wakil Kepala Madrasah Aliyah Negeri 3 Kediri bidang kurikulum mengatakan:

"Problem kurikulum yang ada sekarang ini adalah sebagai berikut: a) banyaknya mata pelajaran, 
akibatnya penguasaan siswa terhadap seluruh mata pelajaran mengambang, setengah-setengah dan kurang matang, ${ }^{34}$ misalnya dari tahun 1994 dulu kelas I sejumlah 17 mata pelajaran, 2004 menjadi 19 pelajaran, 2006 menjadi 20 pelajaran, akibatnya beban anak terlalu berat, b) kuri-kulum-nya kurang sepesifik, ini bisa dilihat struktur kurikulum yang ada jumlah mata pelajarannya terlalu banyak, akibatnya anak tidak diantarkan ke fokus pengembangan potensi, minat dan bakat yang ada, misalnya dia punya potensi untuk bahasa, maka seharusnya langsung ke jurusan bahasa, kemudian tidak mengadopsi ke potensi-potensi lain, yang itu tidak relevan dengan potensi, minat dan bakatnya. Contoh ada anak anak pintar kesenian, tetapi begitu pelajarannya banyak, maka potensi anak tidak tersalurkan secara maksimal, karena harus belajar materi kesenian di satu sisi dan belajar sekian banyak materi pada sisi yang lain. ${ }^{35} \mathrm{c}$ ) Untuk penjurusan, kurikulum 1994 mulai kelas II naik kelas III, kurikulum 2004 dan 2006 KTSP kelas X naik kelas XI, ini akibatnya waktu pendalaman materi pelajaran untuk pengembangan potensi, minat dan bakatnya tidak utuh, akan tetapi terkurangi selama dua semester yang pada akhirnya mengurangi kematangan siswa." 36

Kepala Madrasah Aliyah Negeri 3 Kediri lebih menekankan problem kurikulum itu pada proses dan hasil pembelajaran. Lebih jelasnya ia mengatakan: "Problem kurikulum adalah ketika dalam implemmentasinya tidak sesuai dengan rumusan yang ditetapkan. Keberhasilan Kurikulum Berbasis Kompetensi (K BK) adalah tercapainya proses dan hasil pembelajaran. Ukuran keberhasilan KBK adalah tercapainya aspek kognitif, afektif dan psikomotorik. Kenyataan di lapangan bahwa kurikulum 1994, 2004 sampai 2006. Pokoknya danemnya bagus, lulusannya bagus, yaitu yang dikatakan sekolah bagus. KBK sekarang ini di dalam praktek pelaksanaannya yang berjalan adalah ranah kognitif melulu, maka akibatnya ranah afektif dan psikomotorik kurang mendapat penekanan dan perhatian, padahal sesuai dengan tuntutan Kurikulum Berbasis Kompetensi ranah kognitif, afektif dan psikomotorik harus seimbang, maka yang terjadi di lapangan berarti tidak sesuai dengan tuntutan kurikulum yang ada. Kalaupun ada ranah yang lain, itu hanya listeringsaja untuk bahasa Inggris. UNAS yang menonjol adalah kognitif. Di mana-mana keluh kesahnya seperti itu. Misalnya pelajaran fiqih, ukuran anak pandai itu nilainya 9 atau 10, apakah di rumah shalat atau tidak itu tidak dilihat" ${ }^{37}$

Senada dengan itu Taufiq Hidayat mengatakan: bahwa Madrasah Aliyah swasta yang di bawah naungan pesantren, di samping mengikuti kurikulum Pemerintah, juga menambah kurikulum Pesantren sendiri, sehingga jumlah mata pelajarannya lebih bayak karena ada tambahan kurikulum pesantren. Hal ini mengakibatkan beratnya beban pelajaran bagi siswa yang tidak memikiki basis

yang lalu melenceng dari kesepakatan 4 Juli 2005 tersebut. Pada tahun 2005 anggaran yang dialokasikan untuk pendidikan hanya 8,1\% dan 9,1\% pada tahun 2006. Untuk tahun 2007, Menteri Keuangan Sri Mulyani Indrawati mengatakan bahwa pemerintah hanya akan menaikkan anggaran pendidikan maksimal menjadi 10\% dari APBN. Hal tersebut kembali ditegaskan oleh Presiden Susilo Bambang Yudhoyono dalam pidatonya dihadapan anggota D PR dan D PD bahwa pada tahun 2007 sektor pendidikan hanya akan mendapatkan alokasi anggaran sebesar 10,3\%. Kenyataan ini menunjukkan bahwa pditical will pemerintah terhadap pendidikan masih rendah.

${ }^{33}$ Kepala Madrasah Aliyah Negeri Nglawak Kertosono Nganjuk, wawan-cara tanggal 13 Oktober 2007

${ }^{34}$ Sahudi, Wavancara, Kediri, 16 O ktober 2007, Basuki Rahmat, Kediri, 28 September 2007 dan 13 O ktober 2007.

${ }^{35}$ Bahkan dia lebih jauh berkomentar: "saya dulu 2002 pernah mengajukan ke D irjen Pendidikan Islam, agar anak yang belajar computer cukup belajar Word, Exel, perakitan, perbaikan, internet, bahasa Inggris, olahraga, kemudian Akidah. Dan diajuga punya gagasan untuk mensikapi kurikulum 2006, karena materinya banyak, maka pada materi bidang studi tertentu cukup otodidak, seperti bahasa Indonesia karena itu sebagai alat komunikasi, maka tidak perlu diajarkan sampai SMA dan Aliyah, cukup tingkat dasar dan MTs. Biar anak belajar sendiri. setelah saya lontarkan ke teman-teman mereka belum berani. 
pendidikan agama dari pesantren atau madrasah Tsanawiyah. Ia juga mengatakan bahwa beban materi pelajaran yang begitu banyak, sehingga hanya aspek kognitifnya saja yang tercapai, sedangkan aspek afektif dan psikomotoriknya tidak optimal. ${ }^{38}$

Moh Harisuddin ${ }^{39}$ dan Suparno $0^{40}$ mengatakan: bahwa sistem kurikulum sendiri itu menjadi problem, sehingga menyulitkan pihak pelaksana, terutama tataran guru ketika harus mengubah pola pembelajaran, terutama harus mempersiapkan administrasinya, sekarang ini harus ada RPP dan harus ada silabus. Inilah yang membingungkan pihak pengelola terutama kepada para guru, padahal tuntutan pembelajaran harus tercapainya ranah kognitif, afektif dan psikomotorik. Akibatnya tidak semua tuntutan bisa tercapai.

Guru adalah salah satu faktor yang dapat mempengaruhi keberhasilan sebuah pendidikan, sehingga peran guru sangat penting sekali. Untuk itu diperlukan guru yang memiliki kompetensi di dalam menganjar, baik itu kompetensi akademik (proesional), pedagogik, etik dan sosial. Begitu pula di dalam memahami dan mengembangkan kurikulum yang digunakan, maka di sinilah diperlukan seorang guru vak agar mampu menyusun dan mengembangkan kurikulum sesuai dengan kondisi dan kebutuhan siswa, tetapi kenyataannya tidak seluruh guru Madrasah A liyah bisa demikian. Ini disebabkan sumberdaya manusianya masih rendah dan bahkan ada sebagian guru mengajar salah kamar (mengajar tidak sesuai dengan latar belakang pendidikannya), akibatnya adalah metode pengajarannya tidak variatif, monoton, menjenuhkan, kurang menarik perhatian siswa dan tidak maksimal. ${ }^{41}$ Dalam hal ini Abu Aman mengatakan bahwa KTSP menuntut adanya guru mampu untuk menyusun dan mengembangkan silabus sendiri, namun problemnya adalah masih adanya guru yang SD M-nya rendah, belum paham tentang perkembangan kurikulum baru, akibatnya mereka kesulitan menyusun silabus, membuat Rencana Persiapan Pembelajaran, metode mengajarnya juga kurang variatif dan Ia juga mengatakan masih adanya guru yang mengajar bidang studi bukan vaknya, akibatnya penguasaan materi yang diajarkan kurang maksimal. ${ }^{42}$

Komentar dari Moh Harisuddin bahwa problem guru di samping masalah SD M yang paspasan juga ada enam guru (10 \%) yang mengajar salah kamar (di luar vaknya), yaitu: guru PAI mengajar sejarah, guru PAI mengajar ekonomi, guru matematika mengajar fisika, guru ketrampilan mengajar biologi, guru ketrampilan mengajar olahraga, dan karyawan tamatan SMA mengajar geografi, akibatnya kurang maksimal dalam pembelajarannya terutama yang bukan berlatar-belakang tarbiyah (pendidikan) dan kurang menguasai materi pelajaran secara optimal. ${ }^{43}$

Basuki Rahmat menyatakan bahwa terdapat guru vak Pendidikan Agama Islam, tetapi punya keahlian kesenian maka ia mengajar dan melatih kesenian sekalipun itu salah kamar tetap mengajar

\footnotetext{
${ }^{36}$ Sugeng, Wawancara, Kediri, 8 O ktober 2007.

${ }^{37}$ Sahudi, Wavancara, Kediri, 180 ktober 2007

${ }^{38}$ Kepala Madrasah Aliyah Tribakti Kediri, nawancaratanggal 290 ktober 2007

${ }^{39}$ Kepala Madrasah Aliyah Negeri Nglawak Kertosono Nganjuk, wawan-cara tanggal 13 Oktober 2007.

${ }^{40}$ Wakil Kepala Madrasah Aliyah Negeri (MAN) Jember 1, wawancara tanggal 12 Nopember 2007.

${ }^{41}$ Sahudi, Wawancara, Kediri, 14 O ktober 2007, Sugeng, Kediri, 180 ktober 2007, Wakil Kepala Madrasah Aliyah Negeri Jember 1 Bidang Kurikulum, 12 Nopember 2007, Kepala Madrasah Aliyah Negeri 2 Kediri, 8 O ktober 2007 dan Kepala Madrasah Aliyah Tribakti Kediri, 11 Nopember 2007.

${ }^{42}$ Wawancara dengan Kepala Madrasah Aliyah Negeri 3 Kediri, 14 O ktober2007, Wakil Kepala Madrasah A liyah Negeri 3 Kediri Bidang Kurikulum, 18 O ktober 2007, Kepala Madrasah Aliyah Negeri 2 Kediri, 8 O ktober 2007 dan Kepala Madrasah Aliyah Tribakti Kediri, 11 Nopember 2007.
} 
kesenian, akan tetapi dengan adanya sertifikasi guru maka ia di beri jam mengajar Pendidikan Agama Islam sekalipun tidak banyak. ${ }^{44}$

Peserta didik dalam usia dan tingkat kelas yang sama bisa memiliki profil pengetahuan yang berbeda-beda. Hal ini tergantung kepada konteks yang mendorong perkembangan seseorang, sekalipun lingkungan pendidikannya sama, materi pelajarannya sama, dididik oleh guru yang sama, namun hasilnya tidak sama. Ini bisa saja karena latar belakang pendidikannya berbeda, kemampuan daya serap terhadap meteri pelajaran berbeda dan semangat belajarnya berbeda.

Ketidak samaan prestasi belajar siswa itu kalau terlalu jauh antara siswa satu dengan yang lain, maka itu menjadi problem. Oleh karena itu setiap sekolah dan guru selalu berupaya agar murid-muridnya rata-rata memperoleh prestasi secara maksimal sesuai dengan yang diharapkan. Namun kenyataanya tidak seluruh siswa Madrasah Aliyah demikian. Abu Aman mengatakan: D ari yang diterima di MAN 3 Kediri 80 \% lebih siswanya adalah tamatan dari SMP, besic pendidikan Islamnya sangat kurang, bahkan baca tulis al-Q ur'a $>n$ saja kesulitan, maka akibatnya adalah mereka pada saat mengikuti pelajaran agamanya agak berat dan gandb. ${ }^{45}$ Lebih lanjut Wakilnya bidang kurikulum mengatakan: masih adanya siswa yang bingung, di samping terlalu banyaknya mata pelajaran juga memang SD M-nya rendah, akibatnya anak tidak konsen, dan merasa berat mengikuti seluruh mata pelajaran. ${ }^{46}$ Suhudi mengatakan, bahwa sulitnya siswa memahami seluruh beban materi pelajaran bidang studi itu sesebabkan inputnya rendah, akibatnya mereka tidak mampu menyerap seluruh mata pelajaran secara maksimal. ${ }^{47}$

Agak berbeda dengan komentar di atas, Moh. Harisuddin ${ }^{48}$ mengatakan bahwa problem bagi siswa adalah input-nya rendah, sehingga kalau sudah seperti itu yang butuh pintar ternyata gurunya, ya memang ada satu, dua, tiga anak yang memang potensinya bagus, tetapi kalau dibanding dengan yang lain itu masih jauh. Contoh: kemarin ada problem, ketika ujian Nasional lulus $100 \%$, ada satu anak yang tidak mengindahkan program ujian paraktek, anak tidak ada dan guru sampai mencari anak itu dipanggil ke rumahnya, tetapi tidak ketemu, akhirnya dipaksakan tidak lulus, padahal sebetulnya ada peluang lulus, tetapi karena tidak mengikuti ujian praktek, maka ya tidak diluluskan, sebab kalau siswa seperti ini diluluskan, akan berpengaruh pada siswa yang ujian tahun berikutnya. Inilah yang saya maksudkan yang butuh pintar gurunya, akibatnya atpat lulusannya tidak sesuai dengan yang diharapkan.

Taufiq Hidayat memberikan komentar, bahwa kurang mampunya siswa menyerap seluruh materi pelajaran, baik pelajaran umum maupun pelajaran agama, disebabkan inpt-nya rendah, tidak memiliki basicpesantren atau madrasah, dan juga mereka berangkat dari rumah ke madrasah dan pesantren itu karena memang dari anak yang bandel dan malas, sebab orang tua punya harapan, kalau ditaruh di madrasah dan pesantren itu bisa sembuh, agar bandel dan malasnya hilang, tetapi kenyataannya tidak

\footnotetext{
${ }^{43}$ Kepala Madrasah Aliyah Negeri Nglawak Kertosono Nganjuk, wawan-cara tanggal 13 Oktober 2007.

${ }^{44}$ Wakil Kepala Madrasah Aliyah Negeri 3 Kediri Bidang Kurikulum, wawan-cara tanggal 18 Oktober 2007.

${ }^{45}$ Kepala Madrasah Aliyah Negeri 3 Kediri, wawancara tanggal 14 O ktober 2007.

${ }^{46}$ Wawancara dengan Wakil Kepala Madrasah Aliyah Negeri 3 Kediri Bidang Kuri-ku--lum, 18 Oktober 2007.

${ }^{47}$ Kepala Madrasah Aliyah Negeri 2 Kediri, wawancara tanggal 8 O ktober 2007.

${ }^{48}$ Kepala Madrasah Aliyah Negeri Nglawak Kertosono Nganjuk, wawan-cara tanggal 13 Oktober 2007.

${ }^{49}$ Kepala Madrasah Aliyah Tribakti Kediri, wawancara tanggal 29 O ktober 2007

${ }^{50}$ H.A.R. Tilar, Pendidikan, Kebudayaan, dan Masyarakat Madani Indonesia: Strategi Refomasi Pendidikan Nasional, (Bandung:
} 
seluruhnya bisa demikian, maka akibatnya anak-anak yang seperi ini di Madrasah Umum malas, di Madrasah D iniyah malas dan di Pondok pun malas, bahkan kadang-kadang mereka ingin ke luar, karena berat dan terikat. ${ }^{49}$

\section{Pembahasan}

Pembahasan dalam penelitian ini adalah menggunakan teori Tilar, ia mengatakan problem pendidikan yang mempengaruhi pendidikan nasional dewasa ini adalah Sumberdaya guru yang belum profesional. ${ }^{50}$ Menurut Handayani, kurangnya tenaga guru yang profesional, ${ }^{51}$ Mochtar Buchori berpendapat, Problem operasional, yaitu profesionalisme guru masih rendah, dan Abdul Azis mengatakan: Faktor yang menghambat perkembangan madrasah selama ini adalah keterbatasan tenaga guru, ketidak jelasan status guru dan ketidak layakan kualifikasi guru..$^{52}$ Sedangkan dari temuan data yang peneliti dapatkan dari MA menyebutkan bahwa yang melatar belakangi problem institusi Madrasah Aliyah Umum adalah kurangnya tenaga guru yang sesuai dengan kualifikasi keilmuan, $d$ isamping itu juga masih kurangnya tenaga guru yang dibutuhkan. ${ }^{53} \mathrm{D}$ ari itu maka menurut peneliti dapat mengakibatkan adanya guru yang mengajar salah kamar atau di luar vaknya, ini kalau kita konfirmasikan dengan data nasional juga singkron, yaitu masih banyak guru yang mengajar salah kamar atau di luar vaknya (masih ada 25.368 guru atau 28 \%). O leh karena itu rekonstruksi yang perlu dilakukan menurut peneliti adalah melakukan solusi, yaitu perlu adanya pembinaan melalui Musyawarah Guru Bidang Studi (MGMP) dan peningkatan kualitas, melalui studi lanjut. Dalam hal pembinaan ini, juga perlu adanya kesamaan pandangan dan langkah antara dua bersaudara (D epag dan Diknas) kepada para guru Mafakib yang ada di Madrasah Aliyah dan guru agama yang ada di Sekolah Menengah A tas, supaya saling bersinergi agar kualitas guru dapat ditingkatkan, yang pada muaranya pada peningkatan mutu lulusan.

Di sisi lain problem yang terjadi di lapangan disebabkan karena masih banyak sarana-prasarana pembelajaran yang tidak layak, maka dengan tegas Arif Rahman berpendapat, bahwa titik lemahnya pendidikan itu disebabkan karena lemahnya pemerataan pendidikan yang kurang didukung oleh sarana serta prasarana yang memadai. ${ }^{54}$ Sedangkan dari temuan data yang peneliti dapatkan menyebutkan, dari jumlah ruang belajar Madrasah Aliyah terdapat 26.078 ruang belajar, dan hanya 19.455 ruang belajar atau $74,6 \%$ yang baik. Sedangkan sisanya rusak ringan dan rusak berat. Hingga pada tahun pelajaran 2004-2005 terdapat kekurangan ruang belajar sebanyak 6.248, yang terdiri dari 2.931 ruang belajar baru dan 3.317 ruang belajar yang harus diperbaiki. D ari uraian problem tersebut di atas maka menurut peneliti dapat mengakibatkan proses pembelajaran yang kurang kondusif. Oleh karena itu rekonstruksi yang perlu dilakukan menurut peneliti adalah melakukan solusi, yaitu perlu adanya pembangunan gedung, sarana-prasarana pembelajaran di Madrasah Aliyah yang memadai, sehingga proses pembelajaran lebih kondusif, murid betah di dalam kelas dan bisa konsentrasi dalam belajar yang pada akhirnya mendapatkan hasil yang maksimal.

Remaja Rosdakarya, 1999), 49-51

${ }^{51}$ http:/ / ayok. wordpress. Com / 2007 / 06 / 18 / problematika-sistem - pendidikan- indonesia- gagasan-based- syariaeducation/ Ahad, 6 Januari 2007

${ }^{52}$ http:/ /www.kompas.co.id/ kompas-cetak/ 0406/28/ humaniora/ 1112151. htm, 26 Nopem-ber 2007.

${ }^{53}$ Hasil wawancara dengan Kepala Madrasah Aliyah Negeri 3 Kediri, 14 O ktober 2007, Wakil Kepala Madrasah Aliyah Negeri 3 
Selanjutnya pada problem dana anggaran pendidikan, Yahya Umar berpendapat, sudah sangat lama pendidikan agama diperlakukan sebagai lembaga kelas dua dari pendidikan umum. Alokasi anggarannya pun disebut-sebut hanya atas belas kasihan pendidikan umum yang ditahbiskan oleh negara sebagai lembaga kelas satu dengan berbagai keistemewaan menyertainya. ${ }^{55}$ Pendapat tersebut tepat kalau dikaitkan dengan temuan data yang peneliti dapatkan, yaitu tentang anggaran pendidikan tahun 2007 antara D iknas dengan D epag, ${ }^{56}$ memang tidak sebanding dan tidak proporsional bila dihitung dari sisi jumlah lembaga dan siswa dengan prosentase anggaran pendidikan yang diberikan oleh pemerintah kepada dua departemen tersebut. Sebab anggaran Diknas di samping memang banyak, semua dana yang ada, untuk keperluan pendidikan. Berbeda dengan D epag, anggarannya sudah kecil masih dibagi-bagi untuk keperluan selain pendidikan. Akibatnya di Depag, yang untuk khusus pendidikan tidak lebih dari $44 \%$ pada tahun 2007 dari anggaran D epartemen Agama keseluruhan. Maka berakibat fasilitas belajar dan layanan pendidikan menjadi buruk. Oleh karena itu rekonstruksi yang perlu dilakukan menurut peneliti adalah melakukan solusi, yaitu perlu adanya perhatian pemerintah terhadap anggaran pendidikan yang diberikan kepada D epag secara adil dan proporsional, di samping itu D epag juga mengalokasikan dana pendidikan lebih besar, agar bisa mengejar ketertinggalan dengan saudaranya, yaitu Diknas dan tidak selalu dianggap kelas dua. Selanjutnya pemerintah juga konsisten memenuhi kewajibannya melaksanakan Pasal 31 Ayat (4) UUD 1945, yaitu menganggarkan biaya pendidikan minimal $20 \%$ dari total anggaran negara/ daerah, sehingga kendala-kendala yang selalu menghambat kemajuan dunia pendidikan, terutama madrasah bisa teratasi.

Tidak salah, jika ada pendapat mengatakan bahwa Indonesia adalah negara yang paling sering dan senang mengganti dan merubah kurikulum, sehingga tidak salah juga ada orang mengatakan "setiap ganti menteri, ganti kurikulum". Seringnya pergantian dan perubahan kurikulum, yang didasarkan atas kebijakan dan tidak didukung dengan sistem dan studi kelayakan, maka akan berakibat membingungkan para guru dan menimbulkan problem. Mochtar Buchori berpendapat bahwa, pendidikan di Indonesia mengalami problem fundamental, yaitu disebabkan karena pergantian pemimpin satu ke pemimpin yang lain selalu berubah, begitu pula tentang kebijakan pendidikan, tetapi hasil mutunya selalu di bawah negara tetangga yang sama-sama serumpun. ${ }^{57}$ Sedang Tilar mengatakan bahwa problem pendidikan karena kurikulum yang digunakan tidak relevan dengan kebutuhan siswa, jumlah mata pelajarannya terlalu banyak, bebannya terlalu berat dan orientasinya tidak jelas. ${ }^{58}$

Temuan data yang peneliti dapatkan dari Moh Harisuddin, ${ }^{59}$ bahwa sistem kurikulum sendiri itu menjadi problem, sehingga menyulitkan pihak pelaksana, terutama tataran guru ketika harus mengubah pola pembelajaran, terutama harus mempersiapkan administrasinya, sekarang ini harus ada RPP, harus ada silabus. Inilah yang membingungkan pihak pengelola terutama kepada para guru.

Kediri Bidang K urikulum, 18 O ktober 2007, Kepala Madrasah Aliyah Negeri 2 Kediri, 8 O ktober 2007 dan Kepala Madrasah Aliyah Tribakti Kediri, 11 Nopember 2007.

${ }^{54}$ Arif Rahman, "Mengkaji Ulang Ukuran Keberhasilan Pendidikan di Indonesia", dalam Mengurai BenangKusut(Yogyakarta: Pustaka Pelajar, 2003), 199-200.

${ }^{55}$ Yahya Umar, Konsultasi dan Rapat Kerja dengan Pimpinan PTAIS se Kopertais Wilayah IV Surabaya, 2006

${ }^{56}$ Peringkat Sepuluh Besar APBN 2007 D epartemen \& Non D epartemen, dengan rincian sebagai berikut:

1. Departemen Pendidikan Nasional

2. D epartemen Pertahanan

3. D epartemen Pekerjaan Umum

4. Kepolisian Republik Indonesia
$\mathrm{Rp}$

Rp 44.058.392.664, -

32.640.058.467,-

Rp 24.213.446.000,-

Rp 20.041.477.955,- 
Suhudi ${ }^{60}$ dan Basuki Rakmat ${ }^{61}$ memberikan keterangan bahwa problem kurikulum yang ada sekarang ini disebabkan jumlah mata pelajaran terlalu banyak, kurang spesifik, dan penjurusan mulai kelas dua. Dari data temuan problem kurikulum di Madrasah Aliyah dapat dikelompok-kan menjadi empat, yaitu (1) sistem aturannya selalu berubah, (2) jumlah beban bidang studi (jam pelajaran) terlalu banyak, (3) materi pelajarannya kurang spesifik, dan (4) penjurusan mulai kelas 2 (XI).

Dari beberapa problem kurikulum tersebut berakibat: 1) membingungkan para guru, karena seringnya ganti-ganti kurikulum dan format silabus. Format yang satu belum dipahami sepenuhnya, sudah ganti format yang lain, 2) beban siswa terlalu berat untuk menguasai seluruh pelajaran, 3) kurang memfokus dan penguasaan siswa setengah-setengah, dan 4) pendalaman ilmu bidang jurusan waktunya terbatas.

Dari pendapat teori dan kenyataan problem kurikulum yang ada di Madrasah Aliyah setelah dianalisa maka rekonstruksi yang perlu dilakukan menurut peneliti adalah melakukan solusi, yaitu: (1) kurikulum yang digunakan sifatnya fleksibel, menyesuaikan dengan kondisi siswa dan lingkungan (daerah) yang ada, (2) pengurangan atau perampingan terhadap bidang studi atau materi pelajaran, sebab 19 bidang studi (47-55 jam) perminggu adalah suatu beban yang sangat berat, kalau dibandingkan dengan sekolah Menengah Atas yang hanya 15 bidang studi (39 jam) perminggu, (3) Materi jurusan sekurang-kurangnya 5-7 jam, sedangkan yang lain dikurangi dan ditambahkan ke materi jurusan, (4) penjurusan bisa dimulai sejak kelas $\mathrm{X}$, supaya pendalaman dan pematangan ilmu jurusan bisa lebih maksimal.

Salah satu faktor penting keberhasilan sebuah pendidikan adalah guru. Oleh karena itu diperlukan guru yang memiliki kompetensi profesional, pedagogik, etik dan sosial. Begitu pula di dalam memahami dan mengembangkan kurikulum yang digunakan, tetapi kenyataannya tidak seluruh guru MA bisa demikian, karena sumberdaya manusianya masih rendah dan bahkan masih banyak guru mengajar salah kamar, dan ini adalah sebuah problem. Tilar berpendapat, bahwa problem pendidikan di Indonesia adalah kualitas gurunya masih rendah dan salah pegang materi pelajaran. ${ }^{62}$ Mochtar Buchori juga berpendapat bahwa bagian dari problem pendidikan atau kurikulum adalah profesionalisme guru masih rendah, dan ini berakibat juga terhadap mutu lulusan. ${ }^{63}$ Sedangkan Handayani mengatakan, problemnya adalah kurangnya tenaga guru yang profesional. ${ }^{64}$

Temauan data yang peneliti dapatkan dari Suhudi sebagai berikut: problem faktor guru adalah

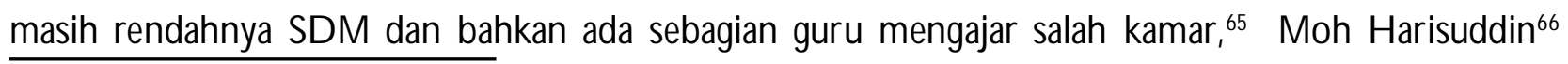

5. D epartemen Kesehatan

6. Departemen Agama*)

7. Departemen Perhubungan

8. Badan Rehabilitasi \& Rekonstruksi NAD

9. D epartemen Keuangan

10.D epartemen Peratanian

*) Termasuk BO Slimpahan dari Dep. Diknas sebesar Rp

${ }^{57}$ http:/ / www.kompas.com/ kompas-cetak/ 0403/ 05/ opini/ 882873.htm Ahad, 6 Januari 2007.

${ }^{58}$ H.A.R. Tilar, BdberapaAgendaRfomas.,30-51.

${ }^{59}$ Kepala Madrasah Aliyah Negeri Nglawak Kertosono Nganjuk, wawan-cara tanggal 13 Oktober 2007.

${ }^{60}$ Sahudi, Wavancara, Kediri, 160 ktober 2007

${ }^{61}$ Basuku Rahmat, Wawancara, Kediri, 17 September 2007.

${ }^{62}$ H.A.R. Tilar, BeberapaAgendaReomas, 30-51.

${ }^{63}$ Mochtar Buchori, http:// www.kompas.com/ kompas-cetak/ 0403/ 05/ opini/ 882873. htm Ahad, 6 Januari 2007.

${ }^{64}$ Handayani, http:/ / ayok. wordpress., Ahad, 6 Januari 2007

Rp 17.236.284.411,-

Rp 10.457.787.919,-

Rp 9.998.812.800,-

Rp 9.607.714.400,-

8.789.618.068,-.

2.074 milyar 
bahwa problem guru di samping masalah SD M yang pas-pasan juga ada enam guru (10 \%) yang mengajar salah kamar (di luar vaknya). Basuki Rahmat6 ${ }^{67}$ bahwa terdapat guru vak Pendidikan Agama Islam, tetapi mengajar kesenian.

Data dari Madrasah Aliyah dapat dikatakan bahwa problem guru, yaitu: (1) sumberdaya manusianya masih rendah, dan (2) masih adanya guru mengajar salah kamar (mengajar tidak sesuai dengan latar belakang pendidikannya), sehingga berakibat: (1) guru tidak faham perkembangan kurikulum baru, kesulitan menyusun silabus, membuat RPP, metode mengajarnya kurang variatif, dan (2) guru kurang menguasai materi pelajaran, menjenuhkan, kurang menarik perhatian siswa dan tidak maksimal.

Dari pendapat teori dan kenyataan problem SD M guru yang ada di MA setelah dianalisa maka rekonstruksi yang perlu dilakukan menurut peneliti adalah melakukan solusi, yaitu: (1) guru bisa melanjutkan ke Program Pascasarjana (S2) yang relevan dengan S1 dan keahliannya, dan (2) mengikut sertakan Musyawarah Guru Mata Pelajaran (MG MP) dengan guru-guru SMA yang serumpun dengan ilmunya dan membentuk teamteahingbidang studi.

Faktor lain adalah faktor siswa. Faktor siswa ini juga menjadi problem tersendiri, seperti latar belakang pendidikan siswa banyak lulusan dari SMP, di samping itu inputnya rendah, anaknya memang bandel, malas, dan tidak memiliki basic agama yang baik. Tilar mengatakan: problem pendidikan di antaranya adalah disebabkan inputnya rendah dan menurunnya moral dan akhlaq peserta didik, rendahnya mutu pendidikan di berbagai jenjang dan jenis pendidikan. ${ }^{68}$ Berbeda dengan Arif Rahman, menurutnya keberhasilan pendidikan (kurikulum) hanya diukur ranah kognitif saja, sedangkan ranah afektif dan psikomotorik kurang mendapat perhatian. ${ }^{69} \mathrm{D}$ ata yang peneliti dapatkan dari Abu Aman ${ }^{70}$ adalah: siswa yang diterima di MAN 3 Kediri 80 \% lebih adalah tamatan dari SMP, basicpendidikan Islamnya sangat kurang, bahkan baca tulis al-Q ur'a $>n$ saja kesulitan. Moh. Harisuddin ${ }^{71}$ berkomentar bahwa problem bagi siswa adalah input-nya rendah, sehingga kalau sudah seperti itu yang butuh pinter ternyata gurunya. Suhudi ${ }^{72}$ dan Suparno ${ }^{73}$ mengatakan: bahwa sulitnya siswa memahami seluruh beban materi pelajaran bidang studi itu disebabkan inputnya rendah. Taufiq Hidayat ${ }^{74}$ mengatakan: bahwa kurang mampunya siswa menyerap seluruh materi pelajaran, baik pelajaran umum maupun pelajaran agama, itu disebabkan input-nya rendah, tidak memiliki besicpesantren atau madrasah.

D ari paparan data yang ada dapat dikatakan bahwa problem siswa yaitu: (1) banyak siswa yang masuk ke MA lulusan dari SMP, (2) inputnya rendah, dan (3) tidak memiliki besicpesantren atau madrasah. D ari problem tersebut berakibat: (1) siswa pada saat mengikuti pelajaran agama, merasa berat dan ketinggalan, (2) anak tidak mampu dan merasa berat mengikuti seluruh mata pelajaran, dan (3) siswa tidak menguasai materi pelajaran, terutama pelajaran agama.

D ari pendapat teori dan kenyataan problem siswa yang ada di MA, maka rekonstruksi yang perlu dilakukan menurut peneliti adalah melakukan solusi, yaitu: (1) menambah mata pelajaran baca tulis

\footnotetext{
${ }^{65}$ Sahudi, Wwawancara, Kediri, 16 O ktober 2007

${ }^{66}$ Kepala Madrasah Aliyah Negeri Nglawak Kertosono Nganjuk, wawancara tanggal 130 ktober 2007.

${ }^{67}$ Wakil Kepala Madrasah Aliyah Negeri 3 Kediri Bidang Kurikulum, wawan-cara tanggal 18 Oktober 2007

${ }^{68}$ H.A.R. Tilar, BeberapaAgendaReormas, 30-51 dan bandingkan H.A.R. Tilar, Pendidikan, Kebudayaa, 49-51.

${ }^{69}$ Arif Rahman, Mengkaji Ulang 199-200.

${ }^{70}$ Kepala Madrasah Aliyah Negeri 3 Kediri, wawancara tanggal 14 O ktober 2007
} 
al-Q ur'a $>n$ di sore hari bagi anak-anak yang masih nol, dan les bahasa Arab, (2) diadakan bina prestasi, baik pelajaran umum maupun agama, bagi anak-anak yang kemampuannya rendah atau menonjol. Bagi yang kemampuannya rendah agar bisa mengejar ketertinggalan-nya dan bagi yang menonjol, bisa termotivasi prestasinya dan dapat ditingkatkan, sehingga memperoleh prestasi tidak hanya di tingkat madrsahnya sendiri, tetapi bisa mencapai prestasi di tingkat lokal, regional dan bahkan nasional, (3) diadakan les materi agama atau dianjurkan sekolah Madrasah D iniyah dan bimbingan khusus, diikut sertakan kelompok belajar siswa dan musyawarah siswa.

\section{Kesimpulan}

Penelitian ini menyimpulkan:

1. Problem Madrasah Aliyah di Indonesia tidak hanya kecilnya dana opersional, tetapi juga kurangnya tenaga guru, ketidak jelasan status guru, ketidak layakan kualifikasi guru, ketidak layakan ruang kelas, dan tidak adanya keseimbangan dana pendidikan antara pendidikan agama dengan pendidikan umum. Akibatnya madrasah dianggap kelas dua, maka rekonstruksi yang perlu dilakukan adalah melakukan solusi, yaitu: a) memberikan anggaran secara adil antara Madrasah dan Sekolah Umum, b) pemerintah harus memenuhi kuwajibannya melaksanakan Pasal 31 Ayat (4) UUD 1945 menganggarkan biaya pendidikan minimal $20 \%$ dari total anggaran negara/ daerah.

2. Problem kurikulum Madrasah Aliyah di Indonesia adalah : a) Sistem dan formatnya selalu berubah, akibatnya membingungkan para guru, maka rekonstruksi yang perlu dilakukan adalah melakukan solusi, yaitu menyesuaikan kurikulum dengan visi misi madrasah dan dengan kondisi yang ada, b) Jumlah mata pelajaran terlalu banyak, akibatnya beban siswa terlalu berat untuk menguasai seluruh pelajaran, maka solusinya adah pengurangan atau perampingan materi pelajaran tertentu, atau jamnya bisa dikurangi, lalu ditambahkan pada materi pokok dan yang lebih relevan, c) Materi pelajarannya kurang spesifik, akibatnya kurang memfokus dan penguasaan siswa setengah-setengah dan kurang matang, maka solusinya adalah materi jurusan sekurang-kurangnya 5-7 jam, sedangkan yang lain dikurangi dan ditambahkan ke materi jurusan, d) Penjurusan mulai kelas II, akibatnya pendalaman ilmu bidang jurusan waktunya kurang, maka solusinya adalah penjurusan dimulai kelas I.

Problem kurikulum berikutnya adalah dari faktor guru, yaitu a) Sumberdaya manusianya masih rendah, akibatnya tidak faham perkembangan kurikulum baru, kesulitan menyusun silabus, membuat rencana persiapan pembelajaran dan metode mengajarnya kurang variatif, maka rekonstruksi yang perlu dilakukan adalah melakukan solusi, yaitu melanjutkan ke Pascasarjana (S2) yang relevan dengan S1 dan keahliannya, b) Masih adanya guru mengajar salah kamar, akibatnya kurang menguasai materi pelajaran, menjenuhkan, kurang menarik perhatian siswa dan mengajarnya tidak maksimal,

\footnotetext{
${ }^{71}$ Kepala Madrasah Aliyah Negeri Nglawak Kertosono Nganjuk, wawancara tanggal 130 ktober 2007.

${ }^{72}$ Kepala Madrasah A liyah Negeri 2 Kediri, wawancara tanggal 8 O ktober 2007.

${ }^{73}$ Wakil Kepala Madrasah Aliyah Negeri Jember 1 , wawancara tanggal 12 Nopember 2007.

${ }^{74}$ Kepala Madrasah Aliyah Tribakti Kediri, wawancara tanggal 29 O ktober 2007.
} 
maka solusinya adalah mengikut sertakan MG MP dengan guru-guru SMA yang serumpun dengan ilmunya dan membentuk teamteadingbidang studi.

Problem kurikulum yang lain adalah dari faktor siswa, yaitu; a) Latar belakang pendidikan siswa banyak lulusan dari SMP, akibatnya siswa pada saat mengikuti pelajaran agama, merasakan berat dan ketinggalan, maka rekonstruksi yang perlu dilakukan adalah melakukan solusi, yaitu menambah pelajaran baca tulis al-Qur'a>n di sore hari bagi anak-anak yang masih nol, dan juga diberi tambahan les bahasa Arab, b) Inputnya rendah, akibatnya anak tidak mampu, dan merasa berat mengikuti seluruh mata pelajaran, maka solusinya adalah diadakan bina prestasi bagi anakanak yang kemampuannya rendah, c) Tidak memiliki basic pesantren atau madrasah, akibatnya tidak menguasai materi pelajaran, terutama pelajaran agama, maka solusinya adalah diadakan les materi agama atau diwajibkan sekolah Madrasah Diniyah

\section{Daftar Rujukan:}

Afandi. A bdullah K hozin dkk., BukuPenunjangBefikirTecritisMarancangProposal. Surabaya: Pascasarjana IAIN Sunan Ampel, 2006.

A rikunto, Suharsimi. Prosedur Penditian Suatu Pendkkatan Praktek. Jakarta: Rineke Cipta, 2002.

Arikunto, Arikunto. Prosedur Penditian. Jakarta: Rineka Cipta, 1993.

al-Abrasyi, A thiyah. Dasar-dasar Pdkdk Pendidikan Islam terj. Bustami A. Gani dan Djohar Basri L.I.S. Jakarta: Bulan Bintang, 1993.

Bullier, Ricard W. The Patriaian of Nisaphur: a Study in Meeieal IslamicSocial Histary. Harvard University Press, 1972.

D anim, Sudarwan. Agenda Penbahanuan Sistem Pendidikan Yogyakarta: Pustaka Pelajar, 2003.

D epag RI. Dara Satatistik Dirktorat Jendral Kdembagaan Agama Isam Jakarta: Sekretariat Bagian D ata dan Informasi Pendidikan, Dirjen Bagais, 2005.

Fieldstead, William J. (ed). Qualitative Methoddogy: Firstthand Invdvement with the Social Wodd Chicago: Markham, 1970.

Gibb, HAR. and Kramers JH. Shater Engdopedia of Islam Lieden: EJ, Brill, 1961.

Guba, EG. dan Lincoln, Y, Effeetive Evaluation, Improving the Usefulness of Evaluation Results through

Responsive and Naturalistic A pproades San Fransisco: Jossey-Bass, Inc, 1981.

Handayani "Problematika Sistem Pendidikan Indone-sia- gagasan-based- syaria-education http:/ / ayok. wordpress. com/ 2007/ 06/ 18/ Ahad, 6 Januari 2007.

Hitti, Philip K. Histary of theArab London: MacMillan Press Ltd., 1974.

K aelan. Meode Penditian Kualitatif Bidang Filsafat. Yogyakarta: Paradigma, 2005.

Maksum. Madrasah; Sejarah dan Pekkembangannya Jakarta: Logos Wacana Ilmu, 1999.

Munawir, A.W. Kams Al-Munauvir Arab Indanesia Surabaya: Pustaka Progresif, 1997.

Mulkhan, Abdul Munir. "D ilema Madrasah di Antara D ua D unia”, dalam Kompas Sabtu, 22 September 2001.

Moleong, Lexy J. Meodblog Penditian Kualitatif Bandung: Remaja Rosda Karya, 1991.

Muhadjir, Noeng. Methode Penditian Kuantitatif Yogyakarta: Rake Sarasin, 2002.

Mulyana, D eddy. Metoddog Penditian Kualitatif, Paradigna Baru Ilmu Kommikasi dan Ilmu Sosial Lainnya. 
Bandung: Remaja Posdakarya, 2001.

Nakosteen, Mehdi. Histary of Isamic Origns of Westem Education A.D. 800-1350, with an Introdurtion to Medieal MusimEducation terj. Joko S Kahar dkk. Colorado: University of Colorado Press, Boulder, 1964.

Nazir, Moh. Meode Penditian Jakarta: G halia Indonesia, 1999.

Rahim, Husni. "Anatomi Madrasah di Indonesia”, dalam Edukas Jurnal Penelitian Pendidikan Agama dan keagamaan, Volume 2, Nomor 2, A pril-Juni 2004.

Rahman, Arif. "Mengkaji Ulang Ukuran Keberhasilan Pendidikan di Indonesia", dalam Mengurai Benang Kusut. Yogyakarta: Pustaka Pelajar, 2003.

Sutjipto. Pendidikan Gun: Masalah dan Stratey Pemeahannya Yogyakarta: Pustaka Pelajar, 2003.

Suparlan, Parsudi. "Pengantar Metodologi Penelitian Kualitatif." Semarang: Fakultas Tarbiyah, Majalah Media edisi 14 tahun 1993.

Syalabi, Syalabi. Sgjarah Kebudayaan Isam Terj. Muhtar Yahya. Jakarta: Jayamurni, 1970.

Tilar, H.A.R. Pendidikan, Kebudayaan, dan Masyarakat Madani Indonesia: Strategj Refomasi Pendidikan Nasional. Bandung: Remaja Rosdakarya, 1999. . BeberapaAgendaRefomas PendidikanNasional dalamPespaktifAbad21. Magelang: Indonesia Tera, 1999.

Umar, Yahya. Konsultasi dan Rapat Kerja dengan Pimpinan PTAIS se Kopertais Wilayah IV Surabaya, 2006. 